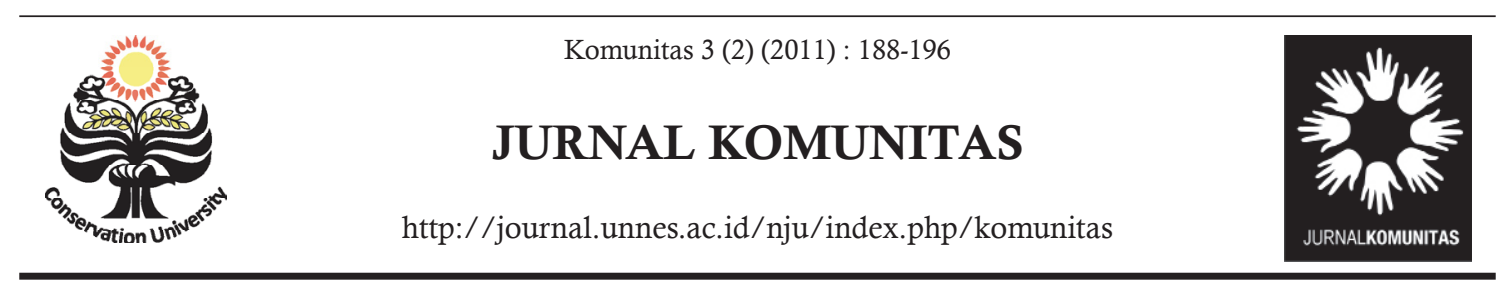

\title{
PENDEKATAN PENDIDIKAN MULTIKULTURAL PADA MATA PELAJARAN SOSIOLOGI SMA KELAS XI
}

\author{
Akbar Wahyu Riyadi $\bowtie$ \\ SMA Permana Purworejo, Jawa Tengah, Indonesia
}

\section{Info Artikel}

Sejarah Artikel:

Diterima Juni 2011

Disetujui Juli 2011

Dipublikasikan September 2011

Keywords:

multicultural;

education;

sociology;

school.

\begin{abstract}
Abstrak
Tujuan penelitian ini adalah untuk menggambarkan penggunaan pendekatan pendidikan multikultural pada pelajaran Sosiologi SMA kelas XI. Penelitian ini merupakan penelitian kualitatif yang dilakukan di SMAN 4 Purworejo. Data dikumpulkan melalui metode pengamatan dan wawancara dengan guru Sosiologi SMAN 4 Purworejo. Hasil penelitian menunjukkan bahwa karakteristik Pendekatan Pendidikan multikultural yang dilakukan oleh guru sosiologi SMA menekankan pada tiga bentuk: optimalisasi peran rasionalitas bagi siswa, praktek dan pembiasaan perbedaan pendapat. Pendekatan ini tepat dilakukan dalam kegiatan pembelajaran pada materi kelompok sosial dalam masyarakat multikultural. Kendala dalam pelaksanaan pendekatan multikultural di SMA adalah, alokasi waktu pertemuan, konsentrasi siswa dalam menerima materi pelajaran yang berhubungan dengan multikultural, keterbatasan media pembelajaran yang digunakan saat pembelajaran serta minat siswa dalam belajar. Hal ini membuat guru bekerja ekstra untuk membuat variasi dalam pembelajaran agar kegiatan belajar mengajar dapat berhasil dengan baik.
\end{abstract}

\begin{abstract}
The objective of this article is to describe the use of multicultural education approach to the study of sociology for senior high school student class XI. This study is a qualitative study conducted in SMAN 4 Purworejo. Data were collected through a method of observation and interviews with teachers of Sociology. The results show that the characteristics of a multicultural approach to education implemented by high school sociology include three forms: teacher's emphasis on the optimization of students' rationality, practice and dissent habituation. This approach is appropriate for the learning activities on material of social groups in multicultural societies. Constraints in the implementation of a multicultural approach in high school include time allocation, student's concentration, the limitations of instructional media used during the learning process, and finally the student's interest in learning. This makes teachers work hard to make the variation in learning in order that teaching and learning activities can have good results.
\end{abstract}

(C) 2011 Universitas Negeri Semarang 


\section{PENDAHULUAN}

Pendidikan adalah suatu cara untuk membentuk kepribadian siswa dalam penerapan nilai-nilai sosial pada masyarakat yang nantinya akan berguna bagi bekal siswa di masa yang akan datang. Pendidikan multikultural sangat penting diterapkan guna meminimalisasi dan mencegah terjadinya konflik, melalui pendekatan multikultural yang diberikan oleh guru dalam menyampaikan pelajaran, siswa diberi pemahaman bahwa manusia adalah mahluk sosial yang saling membutuhkan satu sama lain sehingga mampu mewujudkan keselarasan dalam hidup.

Guru adalah sosok suritauladan yang selalu diamati oleh siswa dan dijadikan inspirasi untuk menambah semangat dalam belajar Serta menuntut ilmu di sekolah, seorang guru memiliki kreatifitas yang tinggi dalam menyampaikan materi pelajaran sehingga materi yang diberikan oleh guru bisa mudah diterima oleh murid-muridnya.

Salah satu aspek yang paling penting untuk dipahami oleh guru dalam pembelajaran adalah karakteristik siswa yang tingkat keberagaman dan latar belakangnya berbeda. Kelompok struktural dalam multikultural dapat diidentifikasi melalui enam kategori, yakni; suku, ras, bahasa, status sosial, religi, dan letak geografis. Keenam kategori ini memiliki persamaan dan keadilan hak untuk mendapatkan pembelajaran dalam kehidupan bernegara (Ennda, 2009).

Konsep kearipan budaya lokal, dalam konteks kehidupan dan relasi sosial ditengah komunitas yang majemuk memiliki kekua$\tan$ (power) dalam menciptakan suasana sosial yang kondusif, maka dengan memahami dan mengangkat kearipan budaya lokal dalam kontek kehidupan ditengah masyarakat yang pluralis, secara sejatinya dapat memberikan peran bagi tertatanya hubungan sosial yang harmoni dengan semangat saling menghargai dan menghormati.

Kebudayaan yang beragam di Indonesia sebagai bagian dari suatu entitas sosial dari budaya mempunyai keunikan dan kekhasan dengan berbagai kebiasaan, adat istiadat dan pengalaman lokal, nilai-nilai sosial dan harapan-harapan hidup yang selalu tidak sama dengan budaya dominan. Fungsi dan tugas lembaga pendidikan harus mengedepankan pola variatif dan mengakui pluralisme sehingga perbedaan tidak menjadi hambatan tetapi menjadi sumber kekuatan untuk hidup berdampingan. Lembaga pendidikan yang mampu mensosialisasikan nilai-nilai multikulturalisme akan lebih terarah dalam pembentukan mental dan pribadi murid bila terintegrasi dalam mata pelajaran atau beberapa materi yang diajarkan di sekolah.

Permasalahan yang terjadi adalah pendekatan seperti apa yang dilakukan oleh guru dalam penyampaian materi-materi pada matapelajaran Sosiologi sehingga siswa dapat memahami adanya perbedaan budaya antar sesama masyarakat sehingga pembelajaran Sosiologi bisa tercapai dengan baik maka perlu diketahui materi-materi yang diberikan, serta kendala yang dihadapi saat pengajaran untuk mengetahui karakteristik siswa, dan sekolah.

Pendekatan yang dikaji adalah tentang penyampaian bahan ajar yang telah dibuat oleh guru dalam proses pembelajaran, meliputi: materi yang diberikan, skenario pembelajaran yang telah dibuat serta pelaksanaan pembelajarannya. Pendekatan yang dilakukan oleh guru SMA Negeri 4 purworejo dalam menyampaikan pembelajaran yang sesuai dengan karakter siswa yang multikultur agar siswa merasa nyaman belajar dan dengan mudah menerima pelajaran.

Pendekatan multikultural ini dapat dilihat dalam pembelajaran oleh guru Sosiologi apapun materinya, misal dalam proses pemberian materi apakah ada pemberian toleransi, solidaritas, musyawarah, dan pengungkapan diri antar siswa, jika ada maka seperti apa, bagaimana, dan dalam hal apa solidaritas, musyawarah, dan pengungkapan diri yang diberikan oleh guru kepada siswa dalam pemberian materi sehari-hari serta bagaimana penanaman pribadi menghargai multikultural kepada siswa agar dapat diketahui pendekatan multikultural yang dilakukan oleh guru.

Pendekatan multikultural yang disampaikan dengan mengiteraksikan dalam materi sehari-hari terutama dalam pembelajaran 
Sosiologi, jika dilaksanakan secara terus menerus maka akan dapat membentuk pribadi siswa yang baik dan menghargai perbedaan antar sesama sehingga keharmonisan dalam hidup pada masyarakat akan tercapai. Pendekatan Multikultural juga dapat disampaikan menggunakan modul sebagai suplemen utama dalam proses pembelajaran khususnya pada mata pelajaran IPS atau social science (Hanum dan Raharja, 2011).

\section{METODE PENELITIAN}

Penelitian ini menggunakan metode penelitian kualitatif. Melalui prosedur penelitian yang menghasilkan data deskriptif berupa kata-kata tertulis atau lisan dari orangorang dan perilaku yang diamati yaitu guru sosiologi di SMA Negeri 4 Purworejo.

Kegiatan penelitian dilakukan untuk mengetahui langkah-langkah dan materi yang diberikan oleh guru sosiologi di SMA Negeri 4 Purworejo dalam pola pendekatan multikultultural di SMA, sehingga data yang dihasilkan bisa didapatkan secara maksimal dan terstruktur sesuai dengan kenyataan yang ada di SMA Negeri 4 Purworejo.

Metode kualitatif digunakan karena beberapa pertimbangan yaitu; menyesuaikan lebih mudah apabila berhadapan dengan kenyataan ganda, metode ini menyajikan secara langsung hakikat hubungan antara peneliti dan responden, metode ini lebih peka dan dapat menyesuaikan diri dengan banyak penajaman pengaruh bersama dan terhadap pola-pola nilai yang dihadapi.

Lokasi dalam penelitian ini adalah SMA Negeri 4 Purworejo, di SMA ini memiliki 2 guru yang mengajar sosiologi, satu lulusan dari prodi sejarah dan satu lagi lulusan dari prodi antropologi sedangkan untuk kelas XI diajarkan oleh guru dari lulusan prodi antropologi. Dalam SMA ini kelas XI terdiri dari 2 kelas yaitu IPS I dan IPS 2 yang terdiri dari 76 murid yang terbagi menjadi 2 yaitu: IPS I terdapat 40 murid dan IPS 2 terdapat 36 murid (sumber: pengolahan data primer bulan oktober 2009).

Murid yang menuntut ilmu di SMA Negeri 4 Purworejo berasal dari sekitar SMA dan dari luar Kabupaten Purworejo . Hal ini membuat tertarik untuk meneliti tentang multikultural dalam melakukan pendekatan pembelajaran karena dalam satu lingkungan dengan murid-murid yang memiliki pola pikir yang berbeda membuat guru lebih aktif dan peka dalam menghadapi kegiatan belajar mengajar.

Fokus penelitian ini adalah pada apa yang dilakukan dalam pendekatan pendidikan multikultural pada mata pelajaran Sosiologi kelas XI SMA Negeri 4 Purworejo yang menjadi sorotan penelitian ini adalah pada apa yang sudah dilakukan oleh guru mata pelajaran Sosiologi dalam memberikan pendidikan multikultural terhadap siswa di SMA Negeri 4 Purworejo secara umum meliputi materi yang diberikan, proses belajarnya, serta seperti apa sikap siswa dalam menanggapi proses pembelajaran. Yang meliputi pola guru dalam penyampaian materi, kendala dan harapan guru serta sikap siswa dalam pelaksanaan proses belajar mengajar. Hal tersebut membuat tertarik penulis karena penulis merasa perlu menambah pengetahuan dan pengalaman tentang pembelajaran dan pola pendekatan yang berhubungan dengan pendidikan.

Subjek penelitian adalah guru sosiologi kelas XI SMA Negeri 4 Purworejo yang berjumlah 1 orang, Alasan pemilihan guru sosiologi kelas XI karena guru sebagai pemberi materi dan pelaksana pengajaran kepada murid yang dapat menerapkan pendekatan pendidikan multikultural.

Sumber data dari penelitian ini terbagi menjadi dua hal, yaitu meliputi data yang sifatnya primer dan sekunder. Data-data primer atau utama diperoleh langsung oleh peneliti melalui wawancara dengan informan. Informan yang dipakai dalam penelitian ini terdiri dari: Infoman utama: adalah ibu guru Sosiologi kelas XI SMA Negeri 4 Purworejo. Data sekunder adalah data yang diperoleh secara tidak langsung dari sumbernya. Dalam penelitian ini data sekunder berasal dari buku, literatur, dokumen penelitian seperti foto-foto, surat kabar yang mendukung dalam penelitian ini, internet dan lain sebagainya. 


\section{HASIL DAN PEMBAHASAN}

Peran atau tanggungjawab guru dan murid dalam mewujudkan kualitas pembelajaran sama besar, guru memiliki peran berkisar $50 \%$, murid juga memiliki peran berkisar $50 \%$. Hal ini menunjukkan bahwa guru dan murid di SMA Negeri 4 Purworejo sama-sama memiliki semangat dan motivasi. Meskipun dilengkapi dengan fasilitas yang sederhana, tetapi kalau guru dan murid tidak memiliki motivasi pembelajaran yang tinggi, maka pembelajaran akan gagal. Guru dan murid dituntut memiliki semangat untuk memanfaatkan segala sarana yang ada disekolah untuk keberhasilan pembelajaran.

Secara umum pembelajaran yang dilakukan masih menggunakan peralatan yang sederhana walau kadang menggunakan media yang berupa LCD dan komputer, tetapi hal itu jarang dilakukan karena harus ada penyesuaian waktu dan kondisi peralatan yang belum sepenuhnya lengkap. Guru selalu mengandalkan murid untuk mencari informasi di luar tapi tugas tetap dikoreksi oleh guru. Pedoman yang sudah digunakan dalam pembelajaran secara umum agar ada penyetaraan konsep dan materi antara guru dengan murid maka guru sosiologi kelas XI di SMA Negeri 4 Purworejo menganjurkan kepada muridnya untuk memiliki buku pejaran dan LKS (Lembar Kerja Murid)

Pendekatan multikultural di SMA Negeri 4 Purworejo dilakukan pada semester genap di kelas XI, proses pemberian pengajaran yang dilakukan oleh guru adalah memberikan pemanasan berupamengulang kembali materi pengertian multikultural dengan pemberian pertanyaan kepada murid agar murid ingat kembali materi yang telah diberikan sebelumnya. Guru memberikan "pemanasan" dengan berdiri di depan kelas dan bercerita tentang multikultural.

Guru menghadapi murid-muridnya dengan penuh senyum dan senang, dengan alasan karena ekspresi senyum dan mendekati murid dapat mengetahui kemampuan murid dan bisa menjadi guru yang diperhatikan oleh muridnya. Setelah memberikan ulasan lalu guru membahas tugas yang telah diberikan yaitu tentang mencari artikel yang berhubungan dengan multikultural yang ada di Indonesia.

Artikel multikultural yang dicari harus bisa menggambarkan keanekaragaman budaya yang bisa menjadi satu, Bu Retno memberikan tugas kepada muridnya untuk mencari artikel-artikel dengan membaca koran. Pada pertemuan berikutnya murid-murid mencari artikel bahkan ada yang membawa koran ke kelas, dan guru pun mengijinkan agar muridnya membawa koran atau majalah ke kelas agar bisa dianalisis bersamasama.

Setelah memberikan ulasan kemudian guru memeriksa tugas yang telah diberikan kepada murid, guru berkeliling di dalam kelas untuk memeriksa satu persatu tugas dan mendengarkan keluhan murid. Kemudian memberikan arahan kepada murid untuk melakukan hal yang benar, jika belum paham maka guru menunjukkan bentuk tugas yang harus dikerjakan dan memberikan sedikit penjelasan kepada murid yang bersangkutan.

Guru dalam memberikan arahan tidak membeda-bedakan dan dengan sabar mendekati murid untuk menanyakan hal apa yang sulit, dan murid menanggapinya dengan baik. Guru secara mendalam berinteraksi dengan murid secara terus menerus. Setelah memberikan masukan kemudian guru menjelaskan pertanyaan murid di depan kelas, dalam memberikan penjelasan guru memberikan sisipan tentang multikultural dan memberikan contoh-contoh yang berhubungan dengan materi dan pertanyaan murid, sehingga murid bisa menjadi tambah paham terhadap materi dan bisa lebih menghargai adanya multikultural dalam kehidupan bermasyarakat.

Setelah tugas diperiksa, kemudian guru menyuruh murid untuk menganalisis hasil kerja masing-masing murid disesuai dengan materi yang diberikan, tetapi menurut pemikiran masing-masing murid berdasarkan pada artikel yang didapatkan murid, proses analisis membutuhkan waktu lama karena murid dituntut untuk berfikir ekstra tentang multikultural. Awalnya murid mengerjakan sendiri-sendiri, tetapi timbul kebingungan pada murid dalam menganalisis hasil kerja, 
sehingga muncul diskusi dengan teman sebangku hal ini mengakibatkan suasana ruang belajar menjadi lebih ramai dan kurang kondisif karena akibat yang ditimbulkan dari diskusi, tapi guru tetap mengawasi muridmurid dalam belajar agar situasi kelas tetap terkontrol oleh guru.

Analisis yang ditugaskan adalah: pengertian multikultural, rangkuman kasus, identifikasi kasus, potensi positif, potensi negatif. Pengertian multikultural disesuaikan dengan materi yang telah diajarkan, rangkuman kasus berupa sinopsis atau cerita singkat yang diambil dari artikel yang ditugaskan dan didapat oleh murid, mengidentifikasi kasus berupa analisis permasalahan dalam artikel yang berhubungan dengan multikultural, potensi positif berupa potensi baik yang ditimbulkan dengan adanya multikultural, potensi negative berupa dampak tidak baik yang di- timbulkan dengan adanya multikultural.

Evaluasi yang dilakukan oleh guru adalah melalui: tes tertulis, membuat uraian, dan diskusi kelompok. Untuk pelaksanaan tes tertulis biasanya dilakukan saat selesai pembelajaran, sedangkan uraian dilakukan saat pembelajaran berlangsung. Diskusi kelompok dilakukan setelah uraian selesai apabila waktu pembelajaran mencukupi. Jika alokasi waktu terbatas maka guru dalam memberikan materi dan evaluasi menggunakan kesempatan-kesempatan tertentu untuk menguji kemampuan masing-masing murid dalam mendalami materi pembelajaran.

Waktu pembelajaran untuk setiap materi diberi alokasi dua jam pelajaran yang disesuaikan dengan Silabus dan RPP yang telah disepakati oleh guru dan kepala sekolah sehingga pendekatan yang digunakan lebih

Tabel 1. Materi pokok dan kegiatan pembelajaran yang dapat menggunakan pendekatan pendidikan multikultural

\begin{tabular}{ll}
\hline Materi pokok/ Pembelajaran & \multicolumn{1}{c}{ Kegiatan Pembelajaran } \\
\hline $\begin{array}{l}\text { Kelompok sosial dalam } \\
\text { masyarakat multikultural }\end{array}$ & $\begin{array}{l}\text { 1. Secara klasikal merumuskan pengertian } \\
\text { kelompok sosial }\end{array}$ \\
2. Secara klasikal mengidentifikasi syarat-syarat \\
dan ciri-ciri kelompok sosial
\end{tabular}

(Sumber: Pengolahan data primer pada Oktober 2009). 
bervariatif agar murid lebih paham terhadap materi yang diberikan.

Guru mengajar dan siswa belajar ada tiga faktor dalam pembelajaran yang mendukung pendekatan multikultural di SMA Negeri 4 Purworejo, yaitu: lingkungan fisik, lingkungan sosial, dan gaya pengajaran guru. Pembelajaran siswa memerlukan lingkungan fisik dan sosial yang aman dan nyaman. Guru mempertimbangkan aspek pencahayaan, warna, pengaturan meja dan kursi, tanaman untuk menciptakan lingkungan fisik yang aman dan nyaman. Guru memiliki pemahaman terhadap latar belakang budaya siswanya, untuk menciptakan lingkungan fisik yang kondusif dalam belajar. guru menggunakan bahasa yang dipilih, hubungan simpatik antar siswa.

Berdasar dari analisis di atas maka pendekatan multikultural secara umum dijelaskan sebagai berikut: Falsafah yang digunakan adalah falsafah teori belajar humanistik, dan konstruktivistik, di mana proses belajar adalah proses memanusiakan manusia dengan cara-cara yang lebih memberikan kebebasan kepada murid dalam mengekspresikan pengetahuannya. Sedangkan teori belajar kontruktivistik adalah bahwa belajar tidak semata-mata membangun konseptual menurut cara pandang kognitif, tetapi belajar adalah memperoleh informasi yanag dibangun melalui pengalaman dilapangan, cara kerja yang dipakai dalam proses pembelajaran multikultural dilakukan dengan cara memberikan kesempatan munculnya ide atau gagasan dari murid. Pemunculan gagasan atau ide dikemas dengan suasana yang menyenangkan atau tidak menakutkan. Murid belajar dengan cara kelompok (group). Guru lebih banyak mengamati perilaku atau aktivitas murid dalam berekspresi terhadap ide atau gagsannya, sumber materi tidak hanya dihasilkan dari guru, tetapi berasal dari semua realitas yang ada disekitarnya. Peran guru hanya sekedar fasilitator, mediator dan memberdayakan sarana pembelajaran agar dapat dijadikan sarana untuk mengoptimalkan pengetahuan dan pemahaman murid, evaluasi tidak hanya dilaksanakan secara instan. Evaluasi harus dilakukan secara simultan, utuh dan komprehensif, artinya evaluasi tidak hanya dimaksudkan untuk mengetahui seberapa besar murid memahami dan menguasai materi dari guru, tetapi evaluasi juga dimaksudkan untuk sarana evaluasi terhadap kekurangan dan kelemahan guru sebagai acuan perbaikan kurikulum dan sarana untuk memperbaiki segala kebijakan dalam pembelajaran.

Pendekatan yang bisa dipakai dalam proses pembelajaran multikultural adalah pendekatan kajian kelompok tunggal (single group studies) dan pendekatan perspektif ganda (multiple perspectives approach). Pendidikan multikultural di Indonesia pada umumnya memakai pendekatan kajian kelompok tunggal. Pendekatan ini dirancang untuk membantu murid dalam mempelajari pandanganpandangan kelompok tertentu secara lebih mendalam, Oleh karena itu, harus tersedia data-data tentang sejarah kelompok itu, kebiasaan, pakaian, rumah, makanan, agama yang dianut, dan tradisi lainnya. Data tentang kontribusi kelompok itu terhadap perkembangan musik, sastra, ilmu pengetahuan, politik dan lain-lain harus dihadapkan pada murid. Pendekatan ini terfokus pada isu-isu yang sarat dengan nilai-nilai kelompok yang sedang dikaji.

Pendekatan perspektif ganda (multiple perspectives) adalah pendekatan yang terfokus pada isu tunggal yang dibahas dari berbagai perspektif kelompok-kelompok yang berbeda. Pada umumnya, guru-guru memiliki berbagai perspektif dalam pembelajarannya.

Pendekatan perspektif ganda membantu murid untuk menyadari bahwa suatu peristiwa umum sering diinterpretasikan secara berbeda oleh orang lain, di mana interpretasinya sering didasarkan atas nilai-nilai kelompok yang mereka ikuti. Solusi yang dianggap baik oleh suatu kelompok (karena solusi itu sesuai dengan nilai-nilainya), sering tidak dianggap baik oleh kelompok lainnya karena tidak cocok dengan nilai yang diikutinya (Enddha, 2009:10).

Keunggulan pendekatan perspektif ganda ini terletak pada proses berpikir kritis terhadap isu yang sedang dibahas sehingga mendorong murid untuk menghilangkan prasangka buruk. Interaksi dengan pandangan kelompok yang berbeda-bebada me- 
mungkinkan murid untuk berempati. Hasil penelitian ini membuktikan bahwa murid yang rendah prasangkanya menunjukkan sikap yang lebih sensitif dan terbuka terhadap pandangan orang lain. Mereka juga mampu berpikir kritis, karena mereka lebih bersikap terbuka, fleksibel, dan menaruh hormat pada pendapat yang berbeda .

Ada beberapa pendekatan dalam proses pendidikan multikultural, yaitu: Tidak lagi terbatas pada menyamakan pandangan pendidikan dengan persekolahan atau pendidikan multikultural dengan program-program sekolah formal. Pandangan yang lebih luas mengenai pendidikan sebagai transmisi kebudayaan membebaskan pendidik dari asumsi bahwa tanggung jawab primer mengembangkan kompetensi kebudayaan di kalangan anak didik semata-mata berada di tangan mereka dan justru semakin banyak pihak yang bertanggung jawab karena program-program sekolah seharusnya terkait dengan pembelajaran informal di luar sekolah, menghindari pandangan yang menyamakan kebudayaan kebudayaan dengan kelompok etnik adalah sama.

Artinya, tidak perlu lagi mengasosiasikan kebudayaan semata-mata dengan kelompok-kelompok etnik sebagaimana yang terjadi selama ini. Dalam konteks pendidikan multikultural, pendekatan ini diharapkan dapat mengilhami para penyusun programprogram pendidikan multikultural untuk melenyapkan kecenderungan memandang anak didik secara stereotip menurut identitas etnik mereka dan akan meningkatkan eksplorasi pemahaman yang lebih besar mengenai kesamaan dan perbedaan di kalangan anak didik dari berbagai kelompok etnik, karena pengembangan kompetensi dalam suatu "kebudayaan baru" biasanya membutuhkan interaksi inisiatif dengan orang-orang yang sudah memiliki kompetensi, bahkan dapat dilihat lebih jelas bahwa upaya-upaya untuk mendukung sekolah-sekolah yang terpisah secara etnik adalah antitesis terhadap tujuan pendidikan multikultural. Mempertahankan dan memperluas solidaritas kelompok adalah menghambat sosialisasi ke dalam kebudayaan baru. Pendidikan bagi pluralisme budaya dan pendidikan multikultural tidak dapat disamakan secara logis, pendidikan multikultural meningkatkan kompetensi dalam beberapa kebudayaan. Kebudayaan mana yang akan diadopsi ditentukan oleh situasi, kemungkinan bahwa pendidikan bahwa pendidikan meningkatkan kesadaran tentang kompetensi dalam beberapa kebudayaan. Kesadaran seperti ini kemudian akan menjauhkan kita dari konsep dwi budaya atau dikhotomi antara pribumi dan non-pribumi. Pendekatan ini meningkatkan kesadaran akan multikulturalisme sebagai pengalaman normal manusia. Kesadaran ini mengandung makna bahwa pendidikan multikultural berpotensi untuk menghindari dikotomi dan mengembangkan apresiasi yang lebih baik melalui kompetensi kebudayaan yang ada pada diri anak didik.

Penerapan Pendekatan Pendidikan Multikultural di aplikasikan pada Materi kelompok sosial dalam masyarakat multikultural. pendidikan multikultural didefinisikan sebagai usaha untuk mengubah sekolah-sekolah dan institusi-institusi pendidikan sehingga siswa dari semua kelas sosial, gender, ras, dan kelompok-kelompok kultural memiliki kesempatan yang sama untuk belajar. Lubis (2007) menyatakan bahwa perubahan yang dilakukan tidak hanya terbatas pada kurikulum, tetapi juga aspek lain seperti metode, strategi, manajemen pembelajaran, dan lingkungan sekolah. Dari aspek prosesnya, pendidikan multikultural dapat dipahami sebagai proses untuk mencapai tujuan agar kesetaraan pendidikan dapat dicapai oleh semua siswa. Kesetaraan pendidikan, seperti kemerdekaan dan keadilan tidak mudah dicapai, karena itu proses ini harus berlangsung terus-menerus.

Pendidikan multikultural diarahkan untuk mewujudkan kesadaran, toleransi, pemahaman, dan pengetahuan yang mempertimbangkan perbedaan kultural, dan juga perbedaan dan persamaan antar budaya dan kaitannya dengan pandangan dunia, konsep, nilai, keyakinan, dan sikap Lawrence J. Saha, 1997:348 dalam (Maulanusantara, 2008).

Tujuan pendidikan multikultural dapat dibedakan menjadi 3 (tiga) macam tujuan, yaitu: tujuan yang berkaitan dengan sikap, pengetahuan, dan pembelajaran (Lawren- 
ce J. Saha, 1997: 349). Tujuan pendidikan multikultural yang berkaitan dengan aspek sikap (attitudinal goals) adalah untuk mengembangkan kesadaran dan kepekaan kultural, toleransi kultural, penghargaan terhadap identitas kultural, sikap responsif terhadap budaya, keterampilan untuk menghindari dan meresolusi konflik.

Tujuan pendidikan multikultural yang berkaitan dengan aspek pengetahuan (cognitive goals) adalah untuk memperoleh pengetahuan tentang bahasa dan budaya orang lain, dan kemampuan untuk menganalisis dan menerjemahkan perilaku kultural, dan pengetahuan tentang kesadaran perspektif kultural. Sedangkan tujuan pendidikan multikultural yang berkaitan dengan pembelajaran (instructional goals) adalah untuk memperbaiki distorsi, stereotip, dan kesalahpahaman tentang kelompok etnik dalam buku teks dan media pembelajaran; memberikan berbagai strategi untuk mengarahkan perbedaan di depan orang, memberikan alat-alat konseptual untuk komunikasi antar budaya; mengembangkan keterampilan interpersonal; memberikan teknik-teknik evaluasi; membantu klarifikasi nilai; dan menjelaskan dinamika kultural.

Hasil penelitian sejenis yang dilakukan oleh Enndha (2009). Pendidikan multikultural (multicultural education) sesungguhnya bukanlah pendidikan khas Indonesia. Pendidikan multikultural merupakan pendidikan khas Barat. Kanada, Amerika, Jerman, dan Inggris adalah beberapa contoh negara yang mempraktikkan pendidikan multikultural. Ada beberapa nama dan istilah lain yang digunakan untuk menunjuk pendidikan multikultural. Beberapa istilah tersebut adalah: intercultural education, inter-ethnic education, transcultural education, multi-ethnic education, dan cross-cultural education.

Pendidikan multikultural adalah sebuah proses pendidikan yang dapat membimbing, membentuk dan mengkondisikan murid agar memiliki mental atau karakteristik terbiasa hidup ditengah-tengah perbedaan yang sangat kompleks, baik perbedaan ideologi, perbedaan sosial, perbedaan ekonomi dan perbedaan agama. Pendidikan mutikultural akan menanamkan sikap kemandirian dalam menyadari dan menyelesaikan segala problem kehidupan para lulusan.

El-Ma'hady (2004) menjelaskan, bahwa inti pendidikan multikultural intinya pada dua hal (a) adanya dialog secara aktif dan partisipatoris. Artinya selama proses pendidikan harus dibiasakan dialog secara intensif dan partisipatoris sehingga murid mampu mengembangkan pengetahuannya secara bebas dan independen. (b) adanya toleransi diantar murid maupun antara murid dan guru serta antara sesama guru. Toleransi ini dimaksudkan membudayakan sikap saling menghormati, menghargai adanya perbedaan baik perbedaan pendapat maupun ideologi yang dilakukan oleh guru maupun murid.

Cara kerja yang dipakai dalam proses pendidikan multikultural adalah dilakukan dengan cara memberikan kesempatan munculnya ide atau gagasan dari murid. Pemunculan gagasan atau ide dikemas dengan suasana yang menyenangkan atau tidak menakutkan, murid belajar dengan cara kelompok (group), guru lebih banyak mengamati perilaku atau aktivitas murid dalam berekspresi terhadap ide atau gagasannya.

Evalauasi tidak hanya dilaksanakan secara instan, evaluasi harus dilakukan secara terus-menerus, artinya evaluasi tidak hanya dimaksudkan untuk mengetahui seberapa besar murid amemahami dan menguasai materi dari guru, tetapi evaluasi juga dimaksudkan untuk sarana evaaluasi terhadap kekurangan dan kelemahan guru, sebagai acuan perbaikan kurikulum, dan sarana untuk memperbaiki segala kebijakan dalam pendidikan.

Model lainnya adalah pendidikan multikultural tidak sekedar merevisi materi pembelajaran tetapi melakukan reformasi dalam sistem pembelajaran itu sendiri. Affirmative action dalam seleksi murid sampai rekrutmen pengajar di Amerika adalah salah satu strategi untuk membuat perbaikan ketimpangan struktural terhadap kelompok minoritas. Contoh yang lain adalah model "sekolah pembauran" Iskandar Muda di Medan yang memfasilitasi interaksi murid dari berbagai latar belakang budaya dan menyusun program anak asuh lintas kelompok. 
Pendekatan pendidikan multikultural tidak lagi terbatas pada menyamakan pandangan pendidikan (education) dengan persekolahan (schooling) atau pendidikan multikultural dengan program-program sekolah formal. Pandangan yang lebih luas mengenai pendidikan sebagai transmisi kebudayaan membebaskan pendidik dari asumsi bahwa tanggung jawab primer menegmbangkan kompetensi kebudayaan di kalangan anak didik semata-mata berada di tangan mereka dan justru semakin banyak pihak yang bertanggung jawab karena program-program sekolah seharusnya terkait dengan pembelajaran informal di luar sekolah.

Robinson Ekstrand, 1997:350 (dalam maulanusantara), membedakan tiga perspektif multikulturalisme di dalam sistem pendidikan: Perspektif "cultural assimilation", Perspektif "cultural pluralism", Perspektif "cultural synthesis". Teori yang dipopulerkan oleh Israel Zangwill ini memandang bahwa individu-individu dalam suatu masyarakat yang beragam latar belakangnya, disatukan ke dalam satu wadah, dan selanjutnya membentuk wadah baru, dengan memasukkan sebagian unsur budaya yang dimiliki oleh masing-masing individu dalam masyarakat tersebut. Identitas agama, etnik, bahasa, dan budaya asli para anggotanya melebur menjadi identitas yang baru, sehingga identitas lamanya menjadi hilang.

Bila dalam suatu masyarakat terdapat individu-individu yang beretnik Jawa, Sunda, dan Batak, misalnya, maka identitas asli dari ketiga etnik tersebut menjadi hilang, selanjutnya membentuk identitas baru. Islam Jawa di kraton dan masyarakat sekitarnya yang merupakan perpaduan antara nilai-nilai Islam dan nilai-nilai kejawen adalah salah satu contohnya.

\section{SIMPULAN}

Karakteristik Pendekatan Pendidikan multikultural yang dilakukan oleh guru sosiologi SMA Negeri 4 Purworejo menekan- kan pada optimalisasi peran rasionalitas bagi siswa, praktek dan pembiasaan perbedaan pendapat, kegiatan pembelajaran pada materi kelompok sosial dalam masyarakat multikultural tepat dilakukan dengan pendekatan pendidikan multicultural, kendala dalam pendekatan multikultural di SMA adalah alokasi waktu pertemuan, konsentrasi siswa dalam menerima materi pelajaran yang berhubungan dengan multikultural, keterbatasan media pembelajaran yang digunakan saat pembelajaran serta minat siswa dalam belajar sehingga membuat guru bekerja ekstra untuk membuat variasi dalam pembelajaran agar kegiatan belajar mengajar dapat berjalan secara harmonis.

Berdasarkan simpulan di atas, maka dapat diberikan saran sebagai berikut: Bagi Guru Sosiologi SMA Negeri 4 Purworejo Nilai-nilai yang diajarkan dalam pendekatan pendidikan multikultural ini dapat diterapkan oleh Murid dalam kegiatan sehari-hari, bagi murid SMA Negeri 4 Purworejo supaya lebih sungguh-sungguh dalam belajar pengetahuan tentang multikultural dalam kehidupan bermasyarakat.

\section{DAFTAR PUSTAKA}

Hanum, F. dan Raharja, S. 2011. Pengembangan Model Pembelajaran Pendidikan Multikultural Menggunakan Modul Sebagai Suplemen Pelajaran IPS di SD. Jurnal Penelitian Ilmu Pendidikan. 4(2)

El-Ma'hady,M. 2010. Multikulturalisme dan Pendidikan Multikultural. Jurnal Penelitian Ilmu Pendidikan. 2(1)

Enndha. 2009. Pembelajaran Multikultural (Multicultural Education). Yogyakarta: Yayasan Obor

Isriani, H. 2011. Pembelajaran Sosiologi Yang Menggugah Minat Siswa. Jurnal Komunitas. 3(1): 108-125

Lubis. 2010. Pembelajaran Berbasis Multikultural. Jurnal Ilmu Pendidikan. 2(1)

Miles, B.M. \& Huberman, A.M. 1992. Analisis Data Kualitatif. Jakarta: UI Press

Moleong. 2004. Metode Penelitian Kualitatif. Bandung: PT. Remaja Rosda Karya

Robinson, Ekstrand dalam Maulanusantara, 2008. Pendidikan Multikultural dalam Tinjauan Pedagogik. Yogyakarta: Pustaka Pelajar 